УДК 82.09 (71):821.111 (18/19)

DOI https://doi.org/10.24919/2308-4863/34-1-15

Наталія БАНДРІВСЬКА, orchid.org/0000-0002-2891-1944 викладач вищзӧ категорії

Дрогобицького механіко-технологічного коледжу (Дрогобич, Львівська область, Украӥна) 20.05.1980.natalia.25@gmail.com

Ольга АНДРІЙЧИК, orchid.org/0000-0002-4161-5701 викладач першої категоріі Дрогобицького механіко-технологічного коледжу (Дрогобич, Львівська область, Україна) andrijchykola@gmail.com

\title{
АНІМАЛІСТИКА ЧАРЛЬЗА РОБЕРТСА ЯК ФЕНОМЕН АНГЛО-КАНАДСЬКОГО ЛІТЕРАТУРНОГО ПРОЦЕСУ КІНЦЯ ХІХ - ПОЧАТКУ ХХ СТ.
}

У статті розглядається проблема анімалістики Чарльза Робертса як феномену англо-канадського літературного процесу кіния XIX - початку XX ст. Цей період вирізняється посиленням інтересу канадських письменників до теми природи, яку осмислювали не тільки як об'єкт зображення, але $і$ як чинник, шео впливав на долю, характер і мислення людини. Канадські письменники (Е. Сетон-Томпсон, Д. Скотт, Ч. Робертс, Сіра Сова та ін.), намагаючись подолати регіоналізм канадської літератури, виробили особливу манеру зображення світу природи, щуо зумовило утвердження нового жанру - анімалістичного оповідання як ключового жанру національної літератури. Анімалістика допомагає нам повернутися до природи. Вона намагається наблизити нас до тієі попередньої спорідненості із землею, не вимагаючи відмовитися від важливих здобутків прожитого часу чи від століттями набутих знань.

Засновником і найбільш талановитим представником иього жанру визнано Чарльза Робертса. Ключові смислові знаки образів природи у творчості Ч. Робертса, послідовне й системне простеження особливостей реалізаиії головних тем і принциів зображення дійсності в його анімалістичних оповіданнях дають змогу говорити про схильність автора до романтичного світосприймання. Саме ие поетичне відчуття природи концентрувалося 8 авторській свідомості у вигляді містичної віри і сприяло зверненню до міфологї. Такі риси міфопоетичної свідомості притаманні анімалістииі Ч. Робертса.

Тема природи, яка особливо активізувалася в кінці XIX - початку XX століть, стала однією з иентральних тем у творчості автора. Чарльз Робертс уперше в англо-канадській літературі звернувся до висвітлення иієі теми, втілюючи своєрідність власне канадського ї̈ трактування. Автор звертається до зображення життя людини в суворих умовах північного краю, до показу суворого, таємничого світу, де $i$ канадський поселенець, $i$ мешканці-тварини приречені співіснувати й вижсиати в жорстоких умовах Півночі. Це співіснування визначає такий домінантний мотив анімалістики Чарльза Робертса, як виживання. Загалом унікальне поєднання автором традиційного та новаторського дає можливість говорити про його своєрідну художню манеру.

Ключові слова: анімалістика, анімалістичне оповідання, скетч. 
Nataliya BANDRIVSKA, orchid.org/0000-0002-2891-1944

Highest Category Teacher

Drohobych Mechanical Technological College

(Drohobych, Lviv region, Ukraine) 20.05.1980.natalia.25@gmail.com

\author{
Olha ANDRIICHYK, \\ orchid.org/0000-0002-4161-5701 \\ First Category Teacher \\ Drohobych Mechanical Technological College \\ (Drohobych, Lviv region, Ukraine) andrijchykola@gmail.com
}

\title{
CHARLES ROBERTS'S ANIMALISM AS A PHENOMENON OF THE ENGLISH-CANADIAN LITERARY PROCESS AT THE END OF XIX - THE BEGINNING OF XX CENTURIES
}

\begin{abstract}
The article deals with the problem of Charles Roberts's animalism as a phenomenon of the English-Canadian literary process at the end of XIX - the beginning of XX centuries. During this period the Canadian authors were highly interested in the theme of nature, which was considered not only as depictive object, but also as the notion that influenced people's fate, character and the way they think. The Canadian authors (E. Seton-Thompson, D. Scott, Ch. Roberts, Grey Owl and others) trying to overcome the regionalism of the Canadian literature, developed a special manner of depicting nature, which led to the establishment of a new genre of animal story as a key genre of the national literature. Animalism helps us to return to the nature. It tries to bring us closer to that previous kinship with the Earth, but not claiming to give up the important achievements of the time or the knowledge acquired over the centuries.

Charles Roberts is considered to be the founder and the most talented representative of this genre. At the same time the key semantic signs of images of nature in his works, his consistent and systematic tracing of the main themes and principles of depiction the reality in his animal stories, allows us to talk about the author's propensity for a romantic worldview. This poetic sense of nature concentrated in the author's consciousness in the form of mystical faith and contributed to the appearing of mythology. These are the features of the mythopoetic consciousness inherent in the animalism of Charles Roberts.

At the end of XIX - the beginning of XX centuries the theme of nature was highly discussed and has become one of the main of Charles Roberts's stories. The author was the first who addressed to the illustration of this theme, pointing to its Canadian treatment. He depicted human's life in severe conditions of North, mysterious world, where either the Canadian settler, or animals have to survive. This coexistence determines such dominant feature of Charles Roberts's animalism as survival. Generally, the unique author's manner of combining the traditional and innovative allows us to talk about his peculiar artistic style.
\end{abstract}

Key words: animalism, animal story, sketch.

Постановка проблеми. Відповідно до тези про те, що нація може бути визначена як письмово зафіксована нарація (Б. Андерсон, Е. Гелнер), жанр оповідання, розглянутий у контексті певної культури, дає змогу виділити певні культурні коди, уможливлює вивчення національних ментальних цінностей. Особливо важливим $\epsilon$ визначення таких кодів у межах тих етнічних систем, які перебувають у процесі самоідентифікації - саме до таких належить культура Канади, яка сформувалася внаслідок багатоаспектних взаємозв'язків у міжкультурних потоках. Саме тому, осмислюючи національну ідентичність канадської літератури, дослідники звертаються до кінця XIX ст. - періоду формування національних літературних традицій і створення передумов для їх подальшого розвитку.

Процес становлення канадської літератури у всій повноті відображає соціокультурні осо- бливості розвитку канадської нації (Єфремова, 1988). Поселенці, які прибули на американський континент, 3 одного боку, зберегли зв'язок 3 європейською культурою (Овчаренко, 1983: 33), a 3 іншого - не могли не відреагувати на специфіку природних умов, у які вони потрапили. Тому в кінці XIX ст. в канадській літературі починають відображатися літературні ознаки «рубежу століть» («pale shadows of the later achievement») (Keith, 1985: 45), з-поміж яких передусім - унікальний синтез романтичних $\mathrm{i}$ модерністських рис. Це стало одним із рушійних чинників посилення інтересу до теми природи, що дедалі активніше й інтенсивніше почала розвиватися у творах канадських письменників. Одним із авторів, творчий інтерес якого майже повністю зосереджений на висвітленні теми природи, а також взаємостосунків людини і природи, був Чарльз Робертс. 
Аналіз досліджень. Аналіз оповідань Ч. Робертса в контексті розвитку західноєвропейської та американської літератур кінця XIX початку XX століть сприяе глибшому розумінню національної специфіки канадської літератури, в історії становлення якої анімалістичне оповідання відіграло ключову роль. Зарубіжні дослідники англо-канадської літератури називають Ч. Робертса «поетом Конфедерації» (Дж. Каппон, Т. Маршал, Д. Пейсі), «письменником прерії» (Дж. Вудкок, А. Лукас), не наголошуючи на історико-літературному значенні його анімалістики. Оскільки вітчизняні дослідники (Н. Овчаренко, А. Голишева, О. Федосюк), на жаль, також не присвячують належної уваги анімалістичним оповіданням Ч. Робертса, у статті розглядаються образностилістичні домінанти анімалістики Ч. Робертса, які безпосередньо пов'язані з порушуваними в його творах проблемами існування та життєдіяльності людини на тлі канадської природи. Це дає підстави для теоретичних узагальнень і висновків про механізм і чинники становлення канадської національної художньої свідомості.

Мета статті - 3'ясувати передумови виникнення анімалістичної прози Ч. Робертса як вагомого складника національної англо-канадської літератури «рубежу століть».

Досягненню цієї мети сприяло розв'язання низки конкретних завдань:

- висвітлити роль анімалістичного оповідання як ключового жанру англо-канадської літератури;

- умотивувати концептуальну роль природи як загального ідейно-естетичного тла й водночас стрижневого концепту анімалістики Ч. Робертса;

- виявити специфіку традиційних поетичних мотивів і образів в анімалістичній спадщині Ч. Робертса.

Виклад основного матеріалу. На «рубежі століть» у канадській літературі склалися специфічні соціокультурні передумови, що сприяли появі жанру анімалістичного оповідання, 3 якого почався процес становлення національної англо-канадської літератури. Зокрема, однією 3 центральних тем у літературі цього періоду стає тема природи. Освоєння новопоселенцями територій канадської Півночі зумовило об'єктивну потребу вивчати іï тваринний і рослинний світ. Крім того, посилення інтересу до світу живої природи підтримувалося також тогочасними новими теоріями, пропагованими в природничих дослідженнях, зокрема концепцією біологічного детермінізму, що склалася під впливом ідей Ч. Дарвіна і Г. Спенсера. Стимульований нею інтерес письменників до світу тварин продуктивно сприяв розвиткові художньої анімалістики (Дж. Лондон, Р. Кіплінг, Дж. Кервуд).

Канадський літературознавець В. Нью визначає animal story як коротку, психологічну, емоційно насичену, логічно завершену оповідь про тварин або $з$ життя тварин (New, 1987: 247). Проте специфіка канадської анімалістики, проблема ії визначення як жанру зумовлена й самою історією ії розвитку, і впливом попередніх літературних форм. Паралельні визначення «narrative», «sketch», «tale» вказують на форми, які передували становленню «animal story» залежно від характеру співвідношення документального і вигаданого.

До Ч. Робертса, як засновника жанру, звернення письменників до співзвучних тем були епізодичними та мали інший характер. Зокрема, упродовж 1830-1850-х pp. замітки про життя поселенців на Півночі друкувала C. Муді (S. Moodie). Однак ці твори мали не стільки художньо-естетичне, скільки дидактичне спрямування. Вони регулярно публікувалися в журналі «Literary Garland» (Монреаль), найвідомішим із них став «Roughing It in the Bush» (1852), і мали документально зафіксувати моральне піднесення, якого зазнає людина, що потрапила в природне середовище після життя в умовах цивілізації.

Окрім С. Муді, до тем, які згодом стали стрижневими для канадської анімалістики, зверталися також М. Стрікленд, Т. Нід, Ф. Стюарт, Д. Трейл. Проте, на думку української дослідниці Н. Овчаренко, їхні твори нагадували радше натуралістичні замітки, документальні свідчення, тому зараховувати їх до творів художньої літератури було б некоректно. Водночас варто зазначити, що в цих творах уже простежуються окремі риси жанру анімалістичного оповідання. Концепцію творчості цих письменників об'єднує спільний погляд на природу як на певне вороже людині середовище, до якого вона прагне, але в якому почувається чужорідним тілом (Овчаренко, 1983: 56). Але саме в цих творах, у їхній формі й предметі зображення, знаходили втілення риси жанру анімалістичного оповідання.

До кінця XIX ст. вже існувало певне розуміння скетчу як «a brief prose work that usually describes a single scene or person, thus minimizing plot and emphasizing the documentary character of the rendering») (New, 1987: 253). Скетч як жанр у цей період вирізнявся лаконізмом. I хоч у ньому було відображено емоційне сприйняття дійсності, популярність його була визначена головним завданням - відображати «фактичний», а не «вигаданий» світ. До «фактичного» нерідко відносили і «враження, отримане від реальної 
дійсності» (Moritz, 1987: 215). Однак ті, хто піддавався спокусі зображати не факт, а враження від нього, усвідомлювали небезпеку повернутися до вихідної позиції в історії канадської літератури, перетворивши розповідь про те, що було насправді, в екзотичну небилицю.

Відсутність єдиного літературного центру в Канаді й тенденція до абсолютизації деталей «місцевого колориту» визначили появу ознак регіоналізму в канадській прозі кінця XIX ст. Проте регіоналізм тогочасних письменників-анімалістів, насамперед Ч. Робертса, співвідноситься не 3 провінціалізмом, що представляе специфіку тієї або іншої території в тї̈ екзотичності, і не 3 націоналізмом, що декларує перевагу своєї нації. Регіоналізм анімалістів співвідноситься 3 національною концепцією, що синтезує 3 окремих елементів загальну картину канадської дійсності, 3 прагненням заявити про повноцінність, самодостатність канадської нації. Письменники цього напряму намагалися збалансувати власну націленість на пошуки національних витоків із бажанням не обмежуватися регіональними проблемами, а ввести канадську літературу у світовий загальнокультурний контекст.

У 90-ті роки XIX ст. починається черговий значний етап розвитку англо-канадської літератури й, зокрема, канадського анімалістичного оповідання, у якому відбулося унікальне поєднання документального та художнього. Цей період пов'язаний 3 іменами Е. Сетона-Томпсона (Е. Seton-Thompson), Ч. Робертса (Ch. Roberts), I. Паркера (G. Parker), згодом - Дж. Кервуда (J. Carwood), Сірої Сови (Grey Owl). Серед них Ч. Робертс визнаний найкращим стилістом в оспівуванні природи.

Інтенсивне розроблення анімалістики у творах Ч. Робертса почалося під враженням від натуралістично точного зображення природи у творах Е. Сетона-Томпсона. У передмові до збірки «Тhe Kindred of the Wild» (1902) Ч. Робертс дав визначення жанру «animal story», оцінюючи його як літературну форму, що «сприяє звільненню від світу громіздких споруд і жалюгідних лабіринтів самосвідомості, у якій ми поступово стаємо втомленими і знесиленими. Анімалістика допомагає нам повернутися до природи, не вимагаючи, щоб ми водночас поверталися до варварства. Вона наближає нас до колишньої спорідненості із землею, не вимагаючи відмовитися від мудрості століть, від важливих результатів прожитого часу. Чисте, щире життя, до якого нас знову підводить анімалістичне оповідання, досі існує за межами переможного маршу людини. Звернення до анімалістичного оповідання має більше значення, ніж просто відновлення сил, це олюднення серця й духу, розуміння нерозривного зв'язку зі світом природи» (Marshall, 1980: 59).

Сучасник Ч. Робертса В. Ф. Стоклі (W. F. Stokley) в журналі «Monthly» ділиться своїми враженнями від перших анімалістичних оповідань Ч. Робертса: «The large place being given to animals in fiction was a sign of decadency!» (Keith, 1985: 18). Водночас він високо оцінює художню манеру письменника i його національну свідомість.

Одним 3 активних періодів пошуків і експериментів в англо-канадській літературі $є$ роки Великої депресії і Другої світової війни. Про це свідчить значна кількість літературних альманахів (Queen's Quarterly, The Canadian Forum, The Canadian Magazine) (W. Grady «Canadian Short Stories», 1981) і радіопрограм (Wednesday Night, Anthology, Canadian Short Stories) (W. H. New «A History of Canadian Literature», 1989). У цей час активізувався літературний процес, з'являються психологічні оповідання М. Лаурі (M. Lowry), спогади Д. Пейсі (D. Расеу), феміністичні замітки Е. Вільсон (E. Wilson), гумористичні оповідання М. Річлера (M. Richler), символічні скетчі П. Пейджа (P. Page), байки А. М. Клейна (A.M. Klein), сентиментальні морські оповідання Е. Баклера (E. Buckler). Більшість цих авторів були новоприбулими громадянами Канади, які прагнули швидше стати «справжніми» канадцями, виявити свою причетність до місцевої культури. Тому в їхні художні системи активно входить екзотичний тваринний і рослинний світ Канади (New, 1987: 79), посилено розробляються проблеми взаємостосунків людини і «чогось невідомого», що розкриваються на тлі суворої канадської природи.

У творах авторів сучасного покоління - М. Етвуд (M. Atwood), Е. Мунро (А. Munro), М. Коена (M. Cohen), В. Вальгардсона (W. D. Valgardson) кореляція «людина - природа» втрачає агресивну конотацію. Як два основні складники навколишнього світу, природа і людина починають висвітлюватися у плані взаємодії, а сам образ природи ускладнюється як складний багатогранний символ.

Варто також зазначити, що роботи письменників - представників ранньої літератури Канади (С. Муді, Т. Халібертона) були скеровані на смаки й життєвий досвід «зовнішнього», дистанційованого читача, що перебуває в Свропі або США. Натомість анімалістика кінця XIX ст. вже виразно орієнтована на місцевого читача - канадця, що замислився про своє місце, про своє самовизначення, про свою національну належність. Звідси своєрідний топос - місце дії - канадських анімалістичних оповідань, упізнаваний завдяки описам рис тваринного і рослинного світу не тільки «місцевим» читачем, але й «зовнішнім». 
Своєрідність канадського анімалістичного оповідання простежується і в незвичайній художній проєкції оповідання. Для американської літератури періоду освоєння характерний так званий горизонтальний погляд «удалину», який охоплює незвідані ліси та прерії, нескінченні сніги. Для англійської літератури кінця XIX століття характерний інший погляд - «згори», погляд із позиції історії і прожитого часу. Для канадської літератури, а саме для розглядуваного англо-канадського анімалістичного оповідання, характерний погляд «зсередини», що визначає локальність як домінантну межу канадського світосприймання. Персонажі творів канадських письменників-анімалістів то мандрують долинами, то провалюються під лід і спостерігають за подіями з дна озера, то потрапляють усередину хижої квітки, то ховаються за дерево, лякаючись невідомого. Така художня проєкція не тільки визначає місце, яке займає людина в системі канадської дійсності, але й дає змогу оцінити низку проблем канадського суспільства, побачених «зсередини».

Особлива система персонажів канадських анімалістичних оповідань зумовлена специфічною проблематикою канадської літератури не тільки цього періоду, але й, на думку М. Етвуд, усією подальшою історією iï розвитку. Такою ключовою ідеєю є ідея «виживання», що з'явилася в анімалістичних оповіданнях кінця XIX - початку $\mathrm{XX}$ століть. Міфологема «виживання» розкриває проблему існування канадця і в суворому світі північної природи, що його оточує, і в умовах політичних, економічних і соціальних зрушень, що спостерігалися в канадському суспільстві в кінці XIX ст. Якщо специфіку літературного героя американської літератури визначає міфологема «американська мрія», в англійській літературі такою є міфологема «будинок-фортеця», то канадська міфологема «виживання» визначає характер героя канадської літератури (Овчаренко, 1983: 22), змушеного думати і дбати про збереження власного життя, забезпечувати собі їжу i житло, максимально остерігаючись водночас навколишнього світу. 3 цього погляду міфологема «виживання» вказує на відмінні риси канадського світосприймання, в іiї символіко-метафізичному значенні сконцентрована проблема виживання молодої канадської нації у період формування i становлення канадської державності.
Творчість Ч. Робертса в окресленому контексті оцінюється як самодостатній і значущий складник національної канадської літератури «рубежу століть». Адже цей письменник започаткував особливий стиль анімалістичного оповідання, у якому відбувається синтез документальності, фактографічності й художності. Цей тип художнього викладу (нарації), власне, й визначив національну специфіку цього жанру малої прози на загальному тлі світової літератури. Крім того, здобуток Робертса-анімаліста полягає в тому, що його твори збагатили світову літературу канадською тематикою.

Висновки. Основні етапи становлення канадської літератури співвідносяться 3 найважливішими історично-культурними віхами розвитку Канади. Вивчення цієї проблеми виявляє низку загальних особливостей, які, з одного боку, зближують іï з іншими національними літературами і передусім із літературами європейських країн, а $з$ іншого - вказують на самобутність канадської літератури в контексті літератури світової.

Домінантна тема англо-канадської літератури загалом і анімалістичного оповідання як феномену саме канадської літератури - тема природи. Ця тема реалізована і в перших канадських твоpax, i в сучасних оповіданнях.

Уперше в історії англо-канадської літератури Ч. Робертс запропонував «внутрішній» погляд новопоселенця на навколишній світ природи.

Тема природи визначає основні стилістичні домінанти анімалістичної прози Ч. Робертса. Саме 3 iï поглибленим розробленням пов'язане активне введення в художньо-образну структуру творів характерних для цього регіону образів рослин, тварин, птахів, природних реалій як основних конкретизаторів універсального образу природи.

Характерна тематична риса творів Ч. Робертса - звернення до зображення життя людини в суворих умовах північного краю, заглиблення в художній показ суворого, таємничого світу, де приречені співіснувати й виживати i канадський поселенець, i мешканці-тварини. Це визначає такий домінантний мотив анімалістики Ч. Робертса, як виживання. Характерна ознака текстового втілення цієї міфологеми - ii накладання і на образ людини, і на образи тварин як основних репрезентантів світу природи, що постійно зазнають зовнішньої небезпеки. 


\section{СПИСОК ВИКОРИСТАНИХ ДЖЕРЕЛ}

1. Овчаренко Н. Ф. Англоязычная проза Канады. Київ : Наукова думка, 1983. 286 с.

2. Проблемы истории Канады / под ред. А. В. Ефремова. Москва : Наука, 1988. 311 с.

3. Keith W. J. Canadian literature in English. L., N. Y., 1985. 287 p.

4. Moritz A., Moritz T. The Oxford Illustrated Literature Guide to Canada. Toronto : Oxford University Press. 1987. 246 p.

5. Marshall T.H. The Major Canadian Poets and the Making of a Canadian Tradition. Vancouver : Vancouver Press, 1980. $184 \mathrm{p}$.

6. New W.H. Dream of Speech and Violence. Toronto : Toronto Press, 1987. 302 p.

\section{REFERENCES}

1. Ovcharenko N. F. Angloyazychnaya proza Kanady. [Canada English-speaking prose]. K., 1983. 286 p. [in Russian].

2. Efremova A. V. Problemy istoriji Kanady. [Problems of Canadian history]. M., 1988. 311 p. [in Russian].

3. Keith W. J. Canadian literature in English. L., N. Y., 1985. 287 p. [in English].

4. Moritz A., Moritz T. The Oxford Illustrated Literature Guide to Canada. Toronto : Oxford University Press. 1987. 246 p. [in English].

5. Marshall T. H. The Major Canadian Poets and the Making of a Canadian Tradition. Vancouver : Vancouver Press, 1980. 184 p. [in English].

6. New W. H. Dream of Speech and Violence. Toronto : Toronto Press, 1987. 302 p. [in English]. 